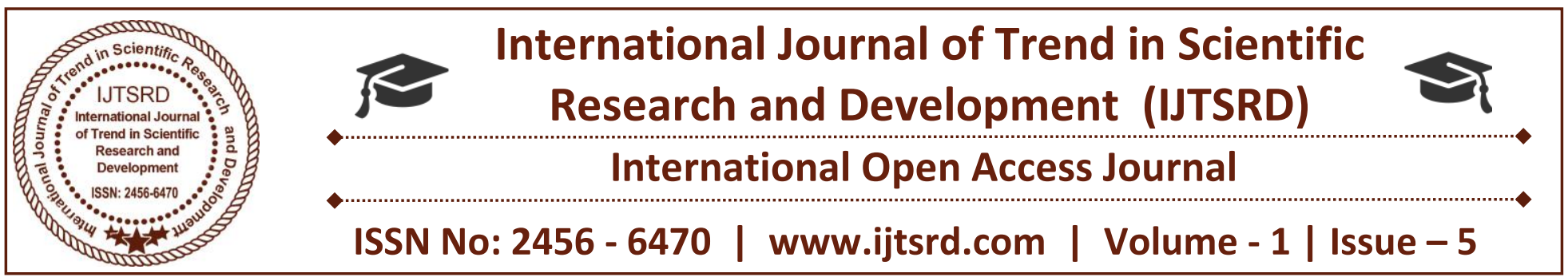

\title{
Analysis of Individual Investors Behaviour of Stock Market
}

\author{
Arup Kumar Sarkar \\ Assistant Professor, \\ Department of Commerce, \\ Sidho-Kanho-Birsha University \\ Purulia, West Bengal, India
}

\section{ABSTRACT}

At the time of investment investors' emotional inclinations, ingrained thought patterns, psychological biases, and other factors may affect their investment behaviour. In this context the research work has made an analysis of individual investors behavior of stock market and main focusof the study is to analyse the effect of demographic factors and investor awareness on the individual investor behaviour and the study is done by using the primary data collected from the selected stock market investors in Purba and Paschim Medinipur district in West Bengal. The results of the association between demographic factors and individual investor behaviour using chi-square test shows that age, educational background and experience has significant effect on the individual investor behaviour in all dimensions. But at the same time occupation has significant effect only on heuristics, prospects and herding dimensions and there is no effect of occupation on the market dimension of individual investor behaviour in stock market in the selected districts. While annual income has significant effect on prospect and herding dimensions but no significant effect on heuristics and market dimensions of investor behaviour in stock market. Analysis of the association between investor awareness and individual investor behaviour shows that knowledge of stock market of an individual investor, following stock market news on T.V and attending seminars affects only his/ her heuristics, markets and herding behaviour but it does not affect on prospects behaviour of individual investor in Purba and Paschim Medinipur district in West Bengal. Further, the issue of following websites of the NSE or
BSE affects individual investor behaviour in stock market on heuristics, markets and herding behaviour but it does not affect on herding behaviour of individual investor in stock market in this two districts. Consultation with licensed brokers or any other intermediary for getting financial advice affect individual investor behaviour in stock market on prospects and markets dimensions but not on heuristics and herding.

Keywords: Stock Market, Behavioural Finance, Demographic Factors, Investor Awareness.

JEL classification: G1, G02

\section{BACKGROUND OF THE STUDY}

An investor's investment decisions in any one particular market, say for example stock market, tend to rely highly on their behaviour derived from psychological principles of decision making as only this psychological principle of decision making can explain why people buy or sell particular stock. Therefore a better understanding of behavioural processes and outcomes is important for financial planners, companies, government, etc. Because an understanding of how investors generally respond to market movements will help them devising appropriate asset allocation strategies, future financial plans, required legislations and macroeconomic policy respectively. In conventional financial theory, investors are assumed to be rational wealthmaximisers, following basic financial rules and on the basis of their investment strategies purely on the risk- 
International Journal of Trend in Scientific Research and Development (IJTSRD) ISSN: 2456-6470

return consideration they generally take their investment decision. Traditional economic theory assumes that people are rational agents who make decisions objectively to take advantage of the opportunities available to them. Investors also think of themselves as rational and logical. But at the time of investment investors' emotional inclinations, ingrained thought patterns, psychological biases, and other factors may affect their investment behaviour. In this backdrop, main focus of the paper is to analysis the effect of demographic factors and investor awareness on the individual investor behaviour and the study is done by collecting primary data from the stock market individual investors in Purba and Paschim Medinipur district in West Bengal. The rest of the study is organized into four sub sections. Section 2 discusses review of some related literature to find out research gaps; section 3 discusses the data and methodology used in the study i.e. the research design; while section 4 presents the analysis and interpretation of the study; and finally, section 5 summarizes the result and concludes the study.

\section{AN OVERVIEW OF THE EXISTING LITERATURE}

Investor behaviour is an area of great interest of the researchers for analysing decision making process and the factors that influences on investment behaviour. A good number of researchers have completed and some others are doing their research work on this area. This section highlights some of the research works on this area. Jagtap and Malpani (2011) ${ }^{1}$ identify that performance of company, nature of industry, company's global exposure highly affect investors' decision while investing in equity market. Dharmaja, et al. $(2012)^{2}$ conclude that majority of the respondents are influenced by the accounting information of the companies and advocate recommendation is the least influencing group. Jain and Mandot (2012) $)^{3}$ explore relationship between level of risk and demographic factors of investors' confined to Rajasthan state. Elankumaran and Ananth $(2013)^{4}$ have investigated that the main factors that have such greater influence are: information asymmetry, objective knowledge, high return and low risk. Lodhi $(2014)^{5}$ says that financial literacy and risk taking are in positive correlation which proves that the financial literacy of a person increases his risk taking capability. Al-Tamimi and Al Anood Bin Kalli $(2009)^{6}$ have examined the financial literacy level of UAE individual investors and the factors that influence their investment decision and they find that the financial literacy is far from the needed level. The UAE investors are more knowledgeable about the benefits of diversification while they are least knowledgeable about the type of UAE financial markets indices. Suman and Warne $(2012)^{7}$ make an attempt to understand individual investor behaviour in stock market. They conduct a survey and collect primary data from a sample around 50 investors of Ambala District. Finally they find that there are different factors which affect the investment behaviour of individual investors such as their awareness level, duration of investment etc. Paul and Bajaj (2012) ${ }^{8}$ find that most of the existing equity investors' possesses a moderate level of awareness about equity market. They also observe that gender and age of the existing equity investors and level of awareness about equity market are not significantly associated. However, there is a significant association between occupation and income and level of awareness level of awareness about equity market. Thus, investment in share market by the retail investors is influenced by their occupation and income. They conclude that for increasing participation of retail investors in the equity market the awareness among them need to be created. Kabra, et, al. $(2010)^{9}$ conclude that the investor's age and gender affect their risk taking capacity. Patidar $(2010)^{10}$ find that age and income affect their risk taking capacity and mostly investors are investing their money through share brokers. Benett, Selvam, Indumathi, Ramkumar and Karpagam (2011) ${ }^{11}$ find that five factors have very high influence over the retail investor's attitude towards investing in equity stocks. They are namely investors' tolerance for risk, strength of the Indian economy, media focus on the stock market, political stability and finally government policy towards business. Babajide and Adetiloye $(2012)^{12}$ find strong evidence that overconfident, loss averse, framing, status quo biases and myopic loss averse exists in the Nigeria security market, though not dominant in the market because they show a low negative relationship, the resultant effect is that the market depreciates in value as investors exhibit behavioural biases. They conclude that being aware of behavioural biases is the crucial first step in ensuring that the decision making process is not adversely affected by them. Undoubtedly, the above mentioned research studies have a great contribution in this field. But the output of a research work depends on various important factors like choice of countries, variable selection, the time period studied, methodology used, etc. It is difficult to 
International Journal of Trend in Scientific Research and Development (IJTSRD) ISSN: 2456-6470

generalize the results because each market is unique in terms of its own rules, regulations, and type of investors. The present study under the title "analysis of individual investor's behaviour of Stock Market" is an endeavour to overcome these limitations through the empirical analysis to come to a valid conclusion.

\section{DATA AND METHODOLOGY}

\subsection{Variables under Study}

In the present study the demographic factors and the investor awareness are consider as independent variables and investor behavior is consider as dependent variable.

\subsubsection{Demographic Factors}

Demographic factors of an investor indicate investor's gender, age, marital status, education, income, occupation etc. Every investor is unique in all aspects due to such demographic factors. So, he can't rely on the decisions already taken by others.

\subsubsection{Investor Awareness}

Awareness refers to the consciousness about a given aspect. There are two types of investors, aware and unaware. Aware investors may know for example the existence and characteristics of a risky asset (bonds and stocks) and have the same information on the probability distribution of the stock return. The others are not aware of stocks. Hence, they can only invest in bonds, regardless of the entry costs. The shadow cost of ignorance is the expected excess return. In stock markets, information is usually transmitted from issuers to investors through several channels mainly through mandatory public disclosure by issuers, voluntary public or private disclosure by issuers; and private acquisition by investors from sources other than the issuer, such as purchasing research reports from stock analysts, examining the firm's products or services, and consulting the firm's competitors among others. In the case of small investors, information relied on is mainly from public disclosure, when professional investors use all channels. Issuers and distributors of financial assets have strong incentives to inform the pool of potential investors. Besides, learning from issuers and distributors, individuals often learn about investment opportunities from peers who have been informed by financial intermediaries (Social learning) and this often occurs depending on the specific process of social learning and on how people interact. On the other hand, awareness can be through financial awareness which is majorly determined by the investor's resources (income, financial wealth), age and education status.

\subsubsection{Investor Behaviour}

The investment behaviour of individual investors is somewhat different from that of institutional investors. Individuals tend to invest relatively more in non-tradable assets such as real estate, hedge funds, or structured products. The term institutional investor is generally used to describe an organization that invests on behalf of others, such as a mutual fund, pension fund, or charitable organization. According to Gerald Appel (2006), investor behaviour is one that an investor displays in searching for purchasing, using, evaluating, and disposing of goods, services, ideas, or experience to satisfy their needs and desires. Individual investor behaviour is influenced by four types of biases such as heuristics biases, prospect biases, market biases and herding biases. Heuristics are defined as the rules of thumb, which makes decision making easier, especially in complex and uncertain environments (Ritter, 2003, p.431) by reducing the complexity of assessing probabilities and predicting values to simpler judgments (Kahneman \& Tversky, 1974, p.1124). Prospect theory describes some states of mind affecting an individual's decision-making processes including regret aversion, loss aversion and mental accounting (Waweru et al., 2003, p.28). Waweru et al. (2008, p.36) identifies the factors of market that have impact on investors' decision making: price changes, market information, past trends of stocks, customer preference, overreaction to price changes, and fundamentals of underlying stocks. Herding effect in financial market is identified as tendency of investors' behaviours to follow the others' actions.

\subsection{Statistical Tools}

To test the association between the independent variable and dependent variable the study uses chisquare test. It is a non-parametric test which is used most frequently to test the statistical significance.

$$
X^{2}=\sum_{i=1}^{n} \frac{\left(O_{i}-E_{i}\right)^{2}}{E_{i}}
$$

Where, $\mathrm{O}_{\mathrm{i}}=$ Observed Frequency

$\mathrm{E}_{\mathrm{i}}=$ Expected Frequency

$\mathrm{n}=$ Number of Variables 


\section{ANALYSIS AND INTERPRETATION}

\subsection{Demographic Factors}

First, it is found that $7 \%$ of respondents are of the age between 18 years to 27 years, $40 \%$ are between 28 years to 37 years, $24 \%$ are between 38 years to 47 years, $16 \%$ are between 48 years to 59 years and $13 \%$ are above 60 years. It is observed that people of between ages of 28 years to 37 years invest most in the stock market (Figure 1). Second, out of 150 sample respondents it is found that $59 \%$ are graduate, $26 \%$ are Post Graduate $7 \%$ are HS and Lower, $4 \%$ are Professional and $4 \%$ are having $\mathrm{Ph}$. D. degree. We can say that most of the investors in the stock market in India are educated. (Figure 2) Third, it is found that farmers are less interested to invest in this segment, businessmen are of $42 \%$, salaried peoples are of $35 \%$, professionals are of $10 \%$, retired are of $7 \%$, others and housewives are of $2 \%$ and students and wage labours are of $1 \%$. It is observed that most of the investors in the stock market in India are businessman in occupation. (Figure 3) Fourth, out of the sample respondents it is found that $23 \%$ of investor are of annual income lower than $100000,61 \%$ of investors are of annual income band from 100000 to 500000 , $12 \%$ are of 500001 to 1000000 , percentage of investor of annual income more than 1000000 is $4 \%$. It is observed that most of the investors in the stock market in India are of an annual income band from 100000 to 500000. (Figure 4) Fifth, it is found that $6 \%$ are less than 1 year, $28 \%$ are from 1 year to 4 years, $37 \%$ are between 5 years to 9 years and $29 \%$ are having 10 years and above years of experience. It is observed that most of the investors in the stock market in India are experienced in this field. (Figure 5)

\subsection{Awareness of sample investors}

First, from the following table it is found that $55 \%$ of sample respondents agree that they are somewhat knowledgeable about stock market activities, 31\% strongly agree that they are somewhat knowledgeable, $10 \%$ are not sure that they are somewhat knowledgeable or not, $1 \%$ of sample respondents say that they are disagreed and 3\% also say that they are strongly disagreed that they are somewhat knowledgeable about stock market activities. So it can be said that Indian investors are aware of stock market activities (Figure 6). Second, out of the 150 sample respondents it is found that $41 \%$ of sample respondents strongly agree that they follow T.V for stock market activities, $43 \%, 5 \%$ and $7 \%$ of sample respondents agreed, strongly disagreed and disagree that they follow T.V for stock market activities respectively. So, we can say that Indian individual investors are aware investors (Figure 7). Third, it is found that $47 \%, 12 \%, 11 \%, 26 \%$ and $5 \%$ of sample respondents are strongly disagreed, agreed, strongly agreed, disagreed and not sure respectively that they attend stock market related seminars, conferences, etc. we can say that Indian individual investors are not aware in respect of attending seminars, conferences, etc. (Figure 8). Fourth, it is found that $37 \%, 7 \%, 35 \%$, $15 \%$ and $6 \%$ of sample respondents say that they strongly agree, strongly disagree, agree, disagree and not sure respectively that they follow websites of NSE and BSE on a timely basis for stock market purpose. So, we can say that Indian individual investors are aware (Figure 9). Lastly, the following table shows that $9 \%, 13 \%, 33 \%, 38 \%$ and $7 \%$ of sample respondents are strongly agree, agree, strongly disagree, disagree and not sure respectively that they consult with the licensed brokers, intermediaries or financial service companies when they need financial advice (Figure 10).

\subsection{Behaviour of Individual Investor in Stock Market}

First, out of 150 randomly taken sample respondents it is found that $39 \%$ strongly agree that they rely on the previous experience for making a further investment in stock market. $45 \%$ agree that they rely on previous experience, $7 \%$ are not sure about their behaviour whether they rely or not, $3 \%$ are strongly disagree and $6 \%$ also disagree that they rely on. We can say that there is a heuristics bias on the Indian individual investor behaviour in stock market (Figure 11). Second, from the survey it is found that $32 \%$ of the sample respondents strongly agree that they always prefer holding the looser stocks (that have decreased in value) and selling winners (that have increased in value). $33 \%$ agree, $14 \%$ strongly disagree, $12 \%$ are not sure and $9 \%$ of the respondents disagree that they always prefer holding looser stocks and selling winners. It indicates that there is some prospect bias in the individual investor behaviour in stock market (Figure 12). Third, out of randomly taken 150 sample respondents $50 \%$ strongly agree that market information is important for their investment in stock market, $40 \%$ agree, $5 \%$ strongly disagree, $4 \%$ not sure whenever, $1 \%$ of respondents disagree that market information is important for their investment in stock market. It indicates that there is some effect of market bias on the individual investor behaviour in 
International Journal of Trend in Scientific Research and Development (IJTSRD) ISSN: 2456-6470

stock market in these two districts (Figure 13). Lastly, from the survey it is found that $47 \%$ of the respondents strongly disagree that they follow other investors at the time of investing in stock market. 27\% disagree, another $13 \%$ agree, $11 \%$ are not sure about their behaviour and another $3 \%$ strongly agree that they follow others at the time of making investment in stock market. It indicates that herding dimension is not strong in individual investor behaviour in stock market in these two districts (Figure 14).

\subsection{Association between demographic factors and individual investor behaviour in stock market in India.}

The above table shows that in case of age, educational background and experience calculated value of chisquare is more than table value in respect of heuristics, prospects, and market and herding dimensions of investor behaviour. So, null hypothesis, there is no effect of demographic factors on the individual investors behaviour in stock market in India, is rejected and we can say that there is impact of age, educational background and experience on the individual investor behaviour in stock market in India in all dimensions. From the above table we can say that in case of occupation, calculated value of chisquare is more than table value in respect of heuristics, prospects and herding dimensions. But calculated value is lower in respect of markets dimensions of investor behaviour. So, Null hypothesis is rejected in case of heuristics, prospects and herding dimensions of investor behaviour so, we can say that there is impact of occupation on the individual investor behaviour in stock market in India in case of heuristics, prospects and herding dimensions. But, in case of market behaviour there is no effect of occupation as calculated value is lower than table value. The above table also indicates that in annual income calculated value of chi-square is greater than the table value in case of prospects and herding dimensions. So, the null hypothesis is rejected and we can say that annual income affect the individual investor behaviour in stock market in India on prospects and herding dimensions. While there is no significant effect of annual income on affect the individual investor behaviour in stock market in India on heuristics and market dimensions as calculated value of chi-square is less than the table value. (Figure 15)

\subsection{Association between investor awareness and individual investor behaviour in stock market}

From the above table, we can say that in case of somewhat knowledge, following T.V and attending seminar the calculated value of chi-square is more than the table value in respect of heuristics, markets and herding behaviour of individual investors. So, the null hypothesis, investor awareness does not influence the individual investor behaviour in stock market in Purba and Paschim Medinipur district, is rejected in these cases. It indicates that somewhat knowledge, following T.V and attending seminar significantly affects the individual investor behaviour in stock market in these two districts only on heuristics, markets and herding behaviour of individual investors. But somewhat knowledge, following T.V and attending seminar has no affect on prospects behaviour as calculated value of chi-square is less than the table value of chi-square. The table also shows that following websites has significant effect on individual investor behaviour in stock market in these two districts on heuristics, prospects and markets dimensions only as calculated value of chisquare is more than the table value of chi-square. But no significant effect on herding dimension as calculated value of chi-square is less than the table value of chi-square. From the table we can also see that in case of consultation with the license brokers has significant effect on individual investor behaviour in stock market in Purba and Paschim Medinipur district on prospects and markets dimensions only as calculated value of chi-square is more than the table value of chi-square. But no significant effect on heuristics and herding dimensions as calculated value of chi-square is less than the table value of chi-square. (Figure 16)

\section{CONCLUDING OBSERVATIONS}

This study investigates the effect of demographic factors and investor awareness on the stock market individual investor behaviour in Purba and Paschim Medinipur district. Existing financial and economic literatures advocate a significant effect of demographic factors and investor awareness on the individual and institutional investor behaviour in stock market and in other commodity market. However, some literatures give some contradictory findings on this aspect. These contradictions are the principal motivation behind conducting this research study in Indian context. The study reveals that people of ages between 28 years to 37 years invest most in the stock market in India and most of the investors are 
International Journal of Trend in Scientific Research and Development (IJTSRD) ISSN: 2456-6470

graduate and above in academic qualification. Majority of the investors in the stock market in India are businessman as occupation and most of the investors in the stock market in India are of an annual income band above Rs. 100000 and the investors' objective is long term profit. The study also indicates that there is heuristics; prospects and markets bias on the Indian individual's investor's behaviour in stock market in India. At the same time herding dimension is not strong in individual investor's behaviour in stock market in India. Analysis of the association between demographic factors and individual investor behavior shows that age of individual investor has an effect on the individual investor behavior in India. Marital Status has an impact on the individual investor behavior in the heuristics, prospects and market dimensions. But there is no effect of marital status on herding. It also indicates that educational background has impact on heuristics, prospects and market behavior of an individual investor. But it does not affect herding behavior of an individual investor. Occupation, experience and annual income of an individual investor affect his/her behavior in stock market in India. As per analysis of the association between investor awareness and individual investor behaviour we see that knowledge of stock market of an individual investor, following stock market news on T.V and attending seminars affects only his/her heuristics, markets and herding behaviour but it does not affect on prospects behaviour of individual investor in stock market in these two districts. Whenever, following websites of the NSE or BSE affect individual investor behaviour in stock market on heuristics, markets and herding behaviour but it does not affect on herding behaviour individual investor in stock market in these two districts. Consultation with licensed brokers or any other intermediary for getting financial advice affect individual investor behaviour in stock market in these two districts on prospects and markets dimensions but not on heuristics and herding. So, in line with the earlier findings made by Suman and Warne (2012), Paul and Bajaj (2012), Benett, Selvam, Indumathi, Ramkumar and Karpagam (2011), Babajide and Adetiloye (2012), the findings of this study reveal that there is effect of demographic factors and investor awareness on individual investor behaviour in stock market. The study would help different interested parties to take care of the factors influencing the behaviour for proper planning and decision making. This study suggests some future research to enhance our understanding about the effect of demographic factors and investor awareness on the investor behaviour. Further research studies could either eliminate some of the limitations or expand the scope of investigation in this study. The possible extension of this study is to consider the institutional investors also besides the individual investor, the use of larger sample size and the more diversity of the respondents. But these are beyond the aim of this present study. These are left for further research.

\section{REFERENCES}

1) Jagtap, U. and Malpani, A. (2011). A Study of Investment Parameters in Equity Market with Special Reference to Professionals in Indore. International Referred Reseach Journal, 2(19), 1115

2) Gnani Dharmaja .V, Ganesh .J. and Santhi .V. (2012). A Study on the Individual Investor Behavior with Special Reference to Geojit BNP Paribas Financial Service Ltd, Coimbatore. International Journal of Research in Management \& Technology (IJRMT), 2(2), 243-252.

3) Jain, D. and Mandot, N. (2012). Impact of Demographic Factors on Investment Decision of Investors in Rajasthan. International Refereed Research Journal, 2(3), 81-92.

4) Elankumaran, A. and Ananth, A. A. (2013). Impacting Factors on Individual Investors' Behaviour towards Commodity Market in India. The International Journal's Research Journal of Social Science and Management, 2(12), 147-153.

5) Lodhi, S. (2014). Factors Influencing Individual Investor Behavior: An Empirical Study of City Karachi. IOSR Journal of Business and Management, 2(16), 68-76.

6) Al-Tamimi, Hassan, Hussein A. \& Kalli, Bin Anood Al. (2009). Financial Literacy and Investment Decisions of UAE Investors. The Journal of Risk Finance, 10(5), 500-516.

7) Suman and Warne, D. P. (2012). Investment Behaviour of Individual Investor in Stock Market. International Journal of Research in Finance \& Marketing. 2(2). 243-250.

8) Paul, T. and Bajaj, S. (2012). Influence of Demographic Profile of Equity Investors on Their Level of Awareness about Equity Market. The International Journal of Management. 1(4). 1-12.

9) Kabra, G. Mishra, Prashant K \& Dash, Manoj, K. (2010). Factors Influencing Investment Decisions of Generations in India: An econometric study. Asian Journal of Management Research, 1(1), 308-328 
International Journal of Trend in Scientific Research and Development (IJTSRD) ISSN: 2456-6470

10) Patidar, S. (2010). Investor's Behaviour towards Share Market. International Research Journal, $1(13), 55-57$

11) Benett, E., Selvam, M., Indumathi, G., Ramkumar, R. R. and Karpagam, V. (2011). Factors Influencing Retail Investors' Attitude towards Investing in Equity Stocks: A Study in
Tamil Nadu. Journal of Modern Accounting and Auditing. 7(3). 316-321.

12) Babajide, A. A. and Adetiloye, A. K. (2012). Investors' Behavioural Biases and the Security Market: An Empirical Study of the Nigerian Security Market. Accounting and Finance Research. 1(1). 219-229.

\section{FIGURES}

Figure -1 Distribution of age of Sample Respondents

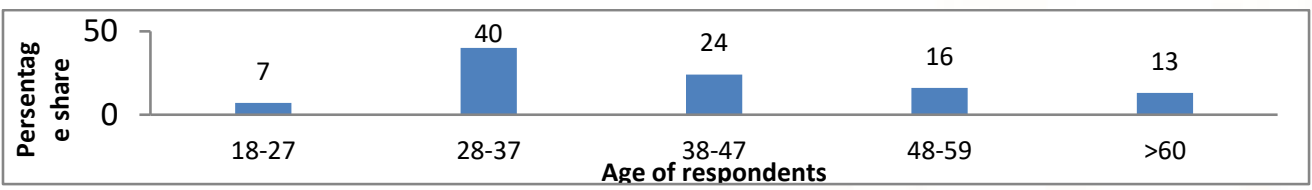

Source: As calculated from primary data

Figure -2 Distribution of level of education of Sample Respondents

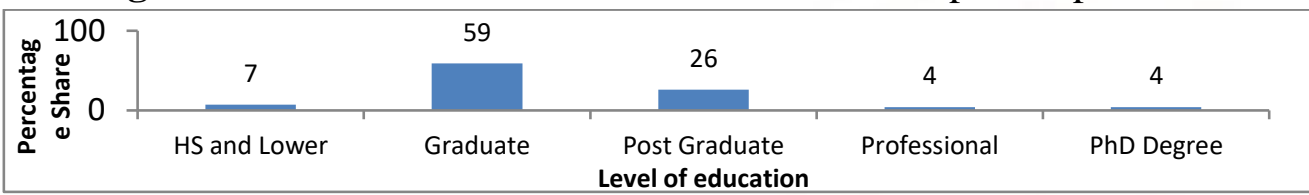

Source: As calculated from primary data

Figure- 3 Distribution of occupation of Sample Respondents

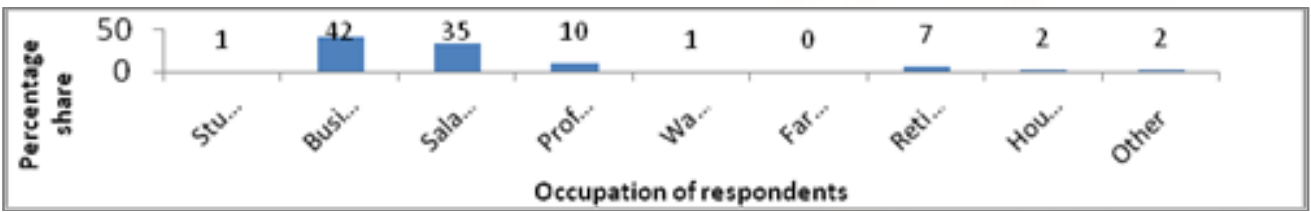

Source: As calculated from primary data

Figure-4 Distribution of annual income of Sample Respondents

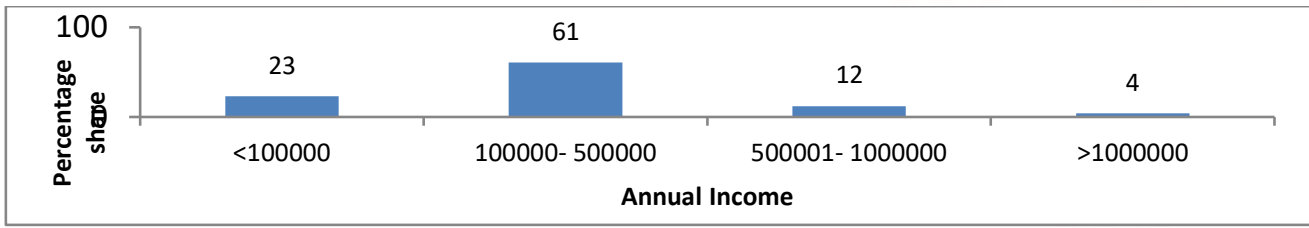

Source: As calculated from primary data

Figure- 5 Distribution of experience of Sample Respondents

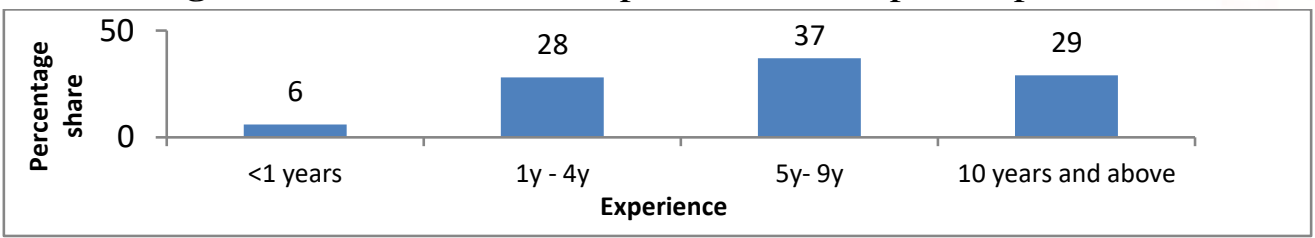

Source: As calculated from primary data 
International Journal of Trend in Scientific Research and Development (IJTSRD) ISSN: 2456-6470

Figure 6 Distribution of somewhat knowledgeable sample respondents

\begin{tabular}{|c|c|c|c|c|c|}
\hline \multirow{2}{*}{ 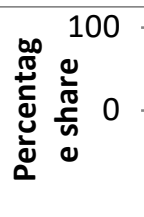 } & 3 & 1 & 10 & 55 & 31 \\
\hline & $\begin{array}{l}\text { Strongly } \\
\text { Disagree }\end{array}$ & Disagree & Not Sure & Agree & Strongly Agree \\
\hline
\end{tabular}

Source: As calculated from primary data

Figure 7 Distribution of sample respondents following T.V

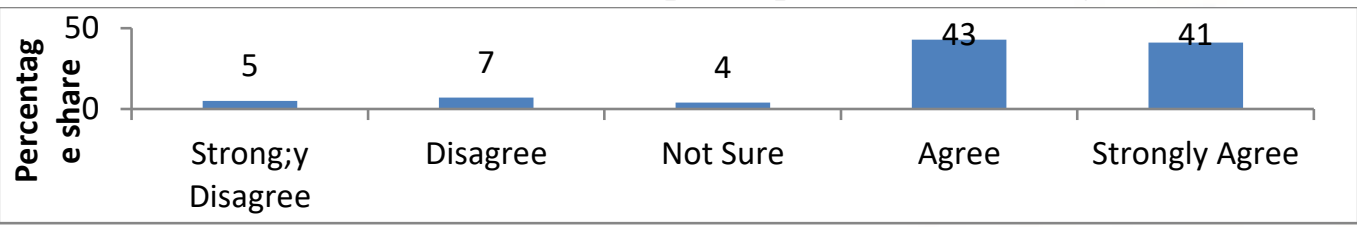

Source: As calculated from primary data

Figure 8 Distribution of sample respondents attending seminars, conferences, etc.

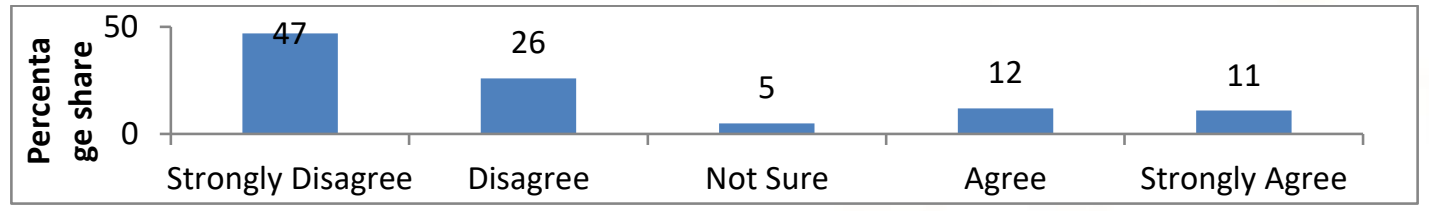

Source: As calculated from primary data

Figure 9 Distribution of sample respondents following websites

\begin{tabular}{|c|c|c|c|c|c|}
\hline \multirow{2}{*}{ 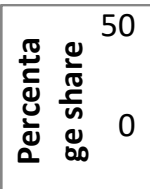 } & 7 & 15 & 6 & 35 & 37 \\
\hline & Strongly Disagree & Disagree & Not Sure & Agree & Strongly Agree \\
\hline
\end{tabular}

Source: As calculated from primary data

Figure 10 Distribution of sample respondents consulting share brokers and others.

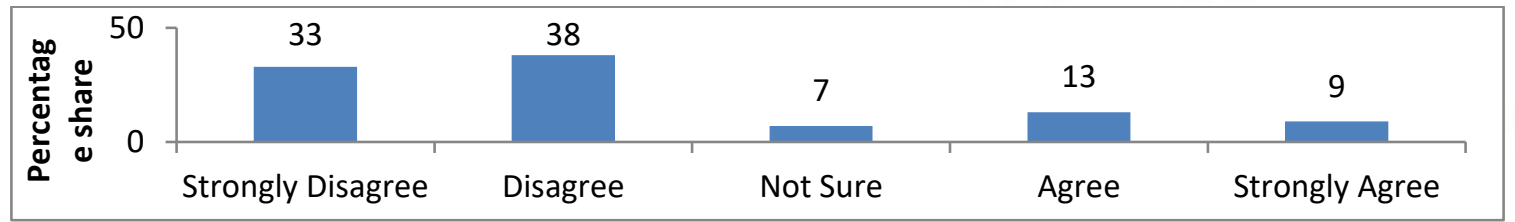

Source: As calculated from primary data

Figure -11 Distributions of sample respondents on heuristics dimension

\begin{tabular}{|c|c|c|c|c|c|}
\hline \multirow{2}{*}{ 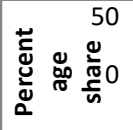 } & 3 & 6 & 7 & & 39 \\
\hline & Strogly Disagree & Disagree & Not Sure & Agree & Strongly Agree \\
\hline
\end{tabular}

Source: Primary Data

Figure -12 Distributions of sample respondents on prospect dimension

\begin{tabular}{|c|c|c|c|c|c|}
\hline \multirow{2}{*}{ 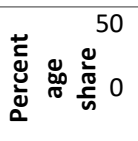 } & 14 & 9 & 12 & 33 & 32 \\
\hline & Strongly Disagree & Disagree & Not Sure & Agree & Strongly Agree \\
\hline
\end{tabular}


International Journal of Trend in Scientific Research and Development (IJTSRD) ISSN: 2456-6470 Source: Primary Data

Figure -13 Distributions of sample respondents on market dimension

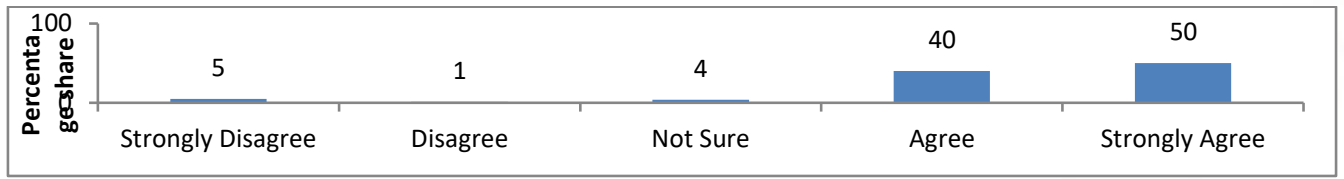

Source: Primary Data

Figure -14 Distributions of sample respondents on herding dimension

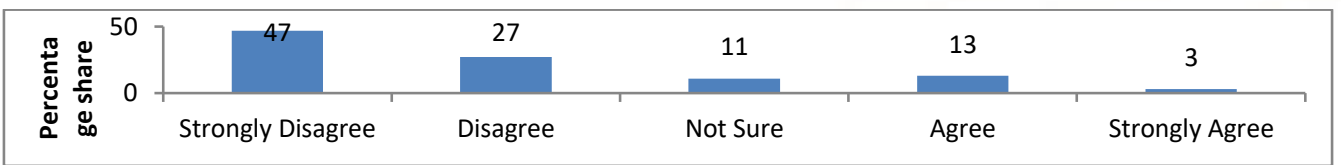

Source: Primary Data

Figure- 15 Test of Association between Demographic Factors and Individual Investor Behaviour by ChiSquare

\begin{tabular}{|c|c|c|c|c|c|c|c|c|c|}
\hline \multirow{3}{*}{$\begin{array}{c}\text { Demographic } \\
\text { Factors }\end{array}$} & \multicolumn{8}{|c|}{ Investor Behaviour } & \multirow{2}{*}{$\begin{array}{c}\text { Level } \\
\text { of } \\
\text { Signifi } \\
\text { cance } \\
(5 \%) \\
\end{array}$} \\
\hline & \multicolumn{2}{|c|}{ Heuristics } & \multicolumn{2}{|c|}{ Prospects } & \multicolumn{2}{|c|}{ Market } & \multicolumn{2}{|c|}{ Herding } & \\
\hline & $\begin{array}{l}\text { Calculated } \\
\text { Value }\end{array}$ & $\begin{array}{l}\text { Table } \\
\text { Value }\end{array}$ & $\begin{array}{c}\text { Calculate } \\
\text { d } \\
\text { Value }\end{array}$ & $\begin{array}{c}\text { Table } \\
\text { Valu } \\
\text { e }\end{array}$ & $\begin{array}{c}\text { Calculat } \\
\text { ed } \\
\text { Value }\end{array}$ & $\begin{array}{c}\text { Tabl } \\
\text { e } \\
\text { Valu } \\
\text { e }\end{array}$ & $\begin{array}{c}\text { Calculate } \\
\text { d } \\
\text { Value }\end{array}$ & $\begin{array}{c}\text { Tabl } \\
\text { e } \\
\text { Valu } \\
\text { e }\end{array}$ & DOF \\
\hline Age & 11.24 & 9.49 & 79.75 & 9.49 & 37.33 & 9.49 & 63.59 & 9.49 & 4 \\
\hline $\begin{array}{l}\text { Educational } \\
\text { Background }\end{array}$ & 25.23 & 9.49 & 21.60 & 9.49 & 69.19 & 9.49 & 19.14 & 9.49 & 4 \\
\hline Occupation & 44.34 & 7.19 & 26.08 & 7.19 & 6.66 & 7.19 & 28.18 & 7.19 & 3 \\
\hline Experience & 58.57 & 7.19 & 78.59 & 7.19 & 65.64 & 7.19 & 38.97 & 7.19 & 3 \\
\hline $\begin{array}{l}\text { Annual } \\
\text { Income }\end{array}$ & 6.94 & 7.19 & 24.06 & 7.19 & 7.16 & 7.19 & 17.61 & 7.19 & 3 \\
\hline
\end{tabular}


International Journal of Trend in Scientific Research and Development (IJTSRD) ISSN: 2456-6470

Figure 16 Test of Association between Investor Awareness and Individual Investor Behaviour by Chi- Square

\begin{tabular}{|c|c|c|c|c|c|c|c|c|c|}
\hline \multirow{3}{*}{$\begin{array}{l}\text { Investor } \\
\text { A wareness }\end{array}$} & \multicolumn{8}{|c|}{ Investor Behaviour } & \multirow{2}{*}{$\begin{array}{c}\text { Level } \\
\text { of } \\
\text { Signif } \\
\text { icanc } \\
\text { e } \\
(5 \%)\end{array}$} \\
\hline & \multicolumn{2}{|c|}{ Heuristics } & \multicolumn{2}{|c|}{ Prospects } & \multicolumn{2}{|c|}{ Markets } & \multicolumn{2}{|c|}{ Herding } & \\
\hline & $\begin{array}{c}\text { Calcul } \\
\text { atedVa } \\
\text { lue }\end{array}$ & $\begin{array}{l}\text { Table } \\
\text { Value }\end{array}$ & $\begin{array}{c}\text { Calcula } \\
\text { tedVal } \\
\text { ue }\end{array}$ & $\begin{array}{l}\text { Table } \\
\text { Value }\end{array}$ & $\begin{array}{l}\text { Calculat } \\
\text { edValue }\end{array}$ & $\begin{array}{l}\text { Table } \\
\text { Value }\end{array}$ & $\begin{array}{l}\text { Calculat } \\
\text { edValue }\end{array}$ & $\begin{array}{l}\text { Table } \\
\text { Value }\end{array}$ & DOF \\
\hline $\begin{array}{c}\text { Somewhat } \\
\text { Knowledgea } \\
\text { ble }\end{array}$ & 6.05 & 3.84 & 0.0031 & 3.84 & 5.17 & 3.84 & 9.87 & 3.84 & 1 \\
\hline Follow T.V & 53.86 & 3.84 & 2.77 & 3.84 & 37.71 & 3.84 & 13.76 & 3.84 & 1 \\
\hline $\begin{array}{c}\text { Attend } \\
\text { Seminars, } \\
\text { Conferences, } \\
\text { etc. }\end{array}$ & 27.22 & 3.84 & 2.12 & 3.84 & 5.31 & 3.84 & 30.35 & 3.84 & 1 \\
\hline $\begin{array}{c}\text { Follow } \\
\text { websites }\end{array}$ & 4.47 & 3.84 & 39.98 & 3.84 & 4.53 & 3.84 & 1.76 & 3.84 & 1 \\
\hline Consultation & 1.90 & 3.84 & 64.43 & 3.84 & 15.73 & 3.84 & 2.91 & 3.84 & 1 \\
\hline
\end{tabular}

Source: as calculated from Primary Data 